\title{
pH-Dependent Solubility and Dissolution Behavior of Carvedilol—Case Example of a Weakly Basic BCS Class II Drug
}

\author{
Rania Hamed, ${ }^{1,4}$ Areeg Awadallah, ${ }^{1}$ Suhair Sunoqrot, ${ }^{1}$ Ola Tarawneh, ${ }^{1}$ Sami Nazzal, ${ }^{2}$ Tamadur AlBaraghthi, \\ Jihan Al Sayyad, ${ }^{1}$ and Aiman Abbas ${ }^{3}$
}

Received 17 May 2015; accepted 7 July 2015; published online 23 July 2015

\begin{abstract}
The objective of this study was to investigate the $\mathrm{pH}$-dependent solubility and dissolution of weakly basic Biopharmaceutical Classification Systems (BCS) class II drugs, characterized by low solubility and high permeability, using carvedilol, a weak base with a $\mathrm{p} K_{\mathrm{a}}$ value of 7.8 , as a model drug. A series of solubility and in vitro dissolution studies was carried out using media that simulate the gastric and intestinal fluids and cover the physiological $\mathrm{pH}$ range of the GI from 1.2 to 7.8. The effect of ionic strength, buffer capacity, and buffer species of the dissolution media on the solubility and dissolution behavior of carvedilol was also investigated. The study revealed that carvedilol exhibited a typical weak base $\mathrm{pH}$-dependent solubility profile with a high solubility at low $\mathrm{pH}(545.1-2591.4 \mu \mathrm{g} / \mathrm{mL}$ within the $\mathrm{pH}$ range 1.2-5.0) and low solubility at high $\mathrm{pH}(5.8-51.9 \mu \mathrm{g} / \mathrm{mL}$ within the $\mathrm{pH}$ range $6.5-7.8)$. The dissolution behavior of carvedilol was consistent with the solubility results, where carvedilol release was complete (95.8-98.2\% released within $60 \mathrm{~min}$ ) in media simulating the gastric fluid ( $\mathrm{pH} 1.2-5.0)$ and relatively low (15.9-86.2\% released within $240 \mathrm{~min})$ in media simulating the intestinal fluid ( $\mathrm{pH}$ 6.5-7.8). It was found that the buffer species of the dissolution media may influence the solubility and consequently the percentage of carvedilol released by forming carvedilol salts of varying solubilities. Carvedilol solubility and dissolution decreased with increasing ionic strength, while lowering the buffer capacity resulted in a decrease in carvedilol solubility and dissolution rate.
\end{abstract}

KEY WORDS: buffer species; carvedilol; dissolution; ionic strength; solubility.

\section{INTRODUCTION}

The dissolution of low-solubility and high-permeability, Biopharmaceutical Classification Systems (BCS) class II drugs, is rate-limiting to oral absorption (1-3). Weakly basic BCS class II drugs such as carvedilol (Fig. 1) exhibit a complex solubility pattern due to the $\mathrm{pH}$ gradient in the gastrointestinal (GI) fluid during transition from the stomach to the intestine. This class of drugs favors ionization and adequate solubilization in the stomach at low $\mathrm{pH}$ (4). However, reaching the intestinal environment (high $\mathrm{pH}$ ), drug precipitation may occur due to its lower aqueous solubility $(4,5)$. Carvedilol, a nonselective beta blocker/alpha-1 blocker, is indicated in the treatment of mild to severe congestive heart failure and high blood pressure. It has a $\log P$ value of 3.8 with a basic $\mathrm{p} K_{\mathrm{a}}$ of 7.8 (6) and an acidic $\mathrm{p} K_{\mathrm{a}}$ of 15.0 (calculated using ChemAxon software). Carvedilol exhibits $\mathrm{pH}$-dependent solubility (7). It dissolves in the acidic $\mathrm{pH}$ of the stomach, as it is presented in

\footnotetext{
$\overline{{ }^{1} \text { Department of Pharmacy, Faculty of Pharmacy, Al-Zaytoonah }}$ University of Jordan, P.O. Box 130Amman, 11733, Jordan.

${ }^{2}$ College of Health and Pharmaceutical Sciences, School of Pharmacy, University of Louisiana at Monroe, Monroe, Louisiana 71201, USA.

${ }^{3}$ Hikma Pharmaceuticals, P.O. Box 182400Amman, 11118, Jordan.

${ }^{4}$ To whom correspondence should be addressed. (e-mail: rania.hamed@zuj.edu.jo)
}

its ionized form. However, in basic $\mathrm{pH}$, carvedilol may precipitate in the distal small intestine $(6,8,9)$. Stillhart et al., for example, found that $78.2-91.8 \%$ of carvedilol precipitates in a crystalline or amorphous form under digestion condition (9). Due to its poor aqueous solubility, carvedilol exhibits very low bioavailability $(10,11)$. The oral absorption of carvedilol was predicted using GastroPlus ${ }^{\mathrm{TM}}$ simulation to be $\sim 45.9 \%$ (6).

In general, dissolution of BCS class II drugs is dependent on a wide variety of physiological factors. $\mathrm{pH}$, ionic strength, and buffer capacity are three major characteristics of the GI fluids that can affect the rate of drug release $(2,12)$. Typical $\mathrm{pH}$ values in the stomach in the fasted state are within the range of 1.4-2.1. In the fed state, the $\mathrm{pH}$ of gastric fluid increases to 3.0-7.0 immediately following a meal, depending on its composition (1). The ionic strength of the gastric fluid is estimated to be in the range of $0.051-0.151 \mathrm{~mol} / \mathrm{L}$, with a median of $0.095 \mathrm{~mol} / \mathrm{L}$ (13). The buffer capacity of human gastric fluids was found to be within the range from 0.013 to $0.019 \mathrm{M} / \Delta \mathrm{pH}$ in the fasted state (14) and approximately $0.028 \mathrm{M} / \Delta \mathrm{pH}$ in the fed state (15). On the other hand, the $\mathrm{pH}$ values in the small intestine gradually rise between the duodenum and ileum to a range of 5.5-8.3, depending on the location and fed and fasted states $(1,14,16)$. This increase in $\mathrm{pH}$ is due to the neutralization of acid coming from the stomach with bicarbonate ions secreted by the pancreas $(1,12)$. The ionic strength of the intestinal fluid was found to be within 
<smiles>COc1ccccc1OCCNC[C@H](O)COc1cccc2[nH]c3ccccc3c12</smiles>

Fig. 1. Chemical structure of carvedilol

the range of $0.070-0.166 \mathrm{~mol} / \mathrm{L}$ (17). The buffer capacity values for human intestinal fluids in the fasted and fed states were reported to be 0.003 and $0.013 \mathrm{M} / \Delta \mathrm{pH}$, respectively (18). Kalantzi et al. measured the buffer capacity of human duodenal aspirates and found that the median buffer capacity in the fasted duodenum was $0.006 \mathrm{M} / \Delta \mathrm{pH}$, which was increased to $0.018-0.030 \mathrm{M} / \Delta \mathrm{pH}$ in the fed state (15).

Since the physiology of GI fluids, such as $\mathrm{pH}$, buffer capacity, and ionic strength, varies as a function of food intake and location within the gastrointestinal tract, studying the influence of these factors on the solubility and dissolution of the weakly basic BCS class II drugs in the GI environment is of considerable interest. The objective of the present work was therefore to study the $\mathrm{pH}$-dependent solubility and dissolution behavior of the weakly basic BCS class II drug carvedilol in simulated gastric and intestinal fluids that cover the physiological $\mathrm{pH}$ range of GI fluids from $\mathrm{pH} 1.2$ to $\mathrm{pH} 7.8$. We also investigated the effect of buffer species, ionic strength, and buffer capacity on the solubility and dissolution behavior of carvedilol from Dilatrend ${ }^{\circledR}$ immediate-release tablets. Our study provides a better understanding of the solubility and in vitro dissolution behavior of weakly basic BCS class II drugs represented by carvedilol under the physiological $\mathrm{pH}$ range of GI fluids. Such understanding serves to improve our knowledge of the dissolution and precipitation behavior of these drugs in the intestine and provide guidance on the development of predictive dissolution methods with improved in vitro-in vivo correlations.

\section{MATERIALS AND METHODS}

\section{Materials}

Carvedilol powder (100.3\% purity and $0.1 \%$ total impurities; Moehs Catalana, S. L., Barcelona, Spain) was provided as a gift from Hikma Pharmaceuticals (Amman, Jordan). No further confirmatory methods were done in our laboratory to substantiate the purity. Dilatrend ${ }^{\circledR}$ immediate-release (IR) tablets, $25 \mathrm{mg}$ carvedilol (ROCHE Australia, lot \# M2049B01), were purchased from the market. Sodium dihydrogen phosphate $\left(\mathrm{NaH}_{2} \mathrm{PO}_{4}\right)$ and disodium hydrogen phosphate $\left(\mathrm{Na}_{2} \mathrm{HPO}_{4}\right)$ were purchased from Sigma-Aldrich (Germany); potassium dihydrogen phosphate $\left(\mathrm{KH}_{2} \mathrm{PO}_{4}\right)$, sodium hydroxide $(\mathrm{NaOH})$, and sodium chloride $(\mathrm{NaCl})$ were purchased from Riedel-de Haën (Germany); acetic acid $\left(\mathrm{CH}_{3} \mathrm{COOH}\right)$ was purchased from ACROS (USA); sodium acetate trihydrate $\left(\mathrm{CH}_{3} \mathrm{COONa} \cdot 3 \mathrm{H}_{2} \mathrm{O}\right)$ was purchased from Fluka (USA); and hydrochloric acid $(\mathrm{HCl}, 37 \% \mathrm{w} / \mathrm{v})$ was purchased from GFS Chemicals (USA). Double-distilled water was obtained using a GFL water distilling apparatus (Germany). All chemical reagents were of analytical grade.

\section{Media Used for Solubility and Dissolution Studies}

Simulated gastric and intestinal fluids were prepared and used in this study. Dissolution media that were used to simulate the gastric fluid are (a) $0.7 \% \mathrm{HCl}$ (USP 38, pH 1.45), (b) simulated gastric fluid without pepsin (SGFsp, USP 38; pH 1.2), (c) blank fasted-state simulated gastric fluid (blank FaSSGF, pH 1.6) (19), and (d) blank fed-state simulated gastric fluid (blank FeSSGF, pH 5.0) (20). Dissolution media that were used to simulate the intestinal fluid are (a) simulated intestinal fluid without pancreatin (SIFsp, USP 26; pH 6.8), (b) $0.05 \mathrm{M}$ phosphate buffer (International Pharmacopeia, IntPh3; pH 6.8) (21), (c) acetate buffer (USP 28, pH 4.5) that simulates the duodenal fluid, (d) blank fasted-state simulated intestinal fluid (blank FaSSIF, pH 6.5), and (d) blank fed-state simulated intestinal fluid (blank FeSSIF, pH 5.0) (22). In this study, the word "blank" refers to dissolution media prepared without the addition of enzymes, surfactants, or bile salts.

In addition to the standard compendial media, simulated intestinal fluid using phosphate buffers of $\mathrm{pH} 6.8$ was prepared using different buffer concentrations $(6.25,12.5,25,50$, and $100 \mathrm{mM}$ ) to obtain media with variable ionic strengths and buffer capacities. Phosphate buffer (100 mM, pH 6.8) was prepared according to the Sigma-Aldrich Buffer Reference Center. Double-distilled water of zero ionic strength and zero buffer capacity was used as a control. Phosphate buffers of $\mathrm{pH} 7.2$ and 7.8 media were also prepared according to the Sigma-Aldrich Buffer Reference Center to simulate the $\mathrm{pH}$ during the fasted state of the proximal ileum $(1,23)$ and colon $(24)$, respectively. The detailed chemical composition and physicochemical properties ( $\mathrm{pH}$, ionic strength, and buffer capacity) of the media used in this study are summarized in Tables I, II, III, and IV.

\section{Physicochemical Properties of the Media}

The $\mathrm{pH}$ of the media was measured using a $\mathrm{pH}$ meter (Mettler Toledo, USA). The $\mathrm{pH}$ meter was calibrated before each measurement. The ionic strength of the solubility and dissolution media was calculated using Eq. (1) (25).

$I=\frac{1}{2} \sum_{1}^{J} c_{i} z_{i}^{2}$

where

$I$ Ionic strength

$J$ Number of species in the solution

$c_{i}$ Molar concentration of ion $i$

$z_{i}$ Charge number of ion $i$

The summation symbol, $\Sigma$, indicates that the products of $c z^{2}$ terms of all the ionic species in the solution, from the first one to the $J$ th species, are to be added together.

The Van Slyke Eq. (2) (21) was used to calculate the buffer capacity of the media:

$$
\beta=2.3 C \frac{K_{\mathrm{a}}\left[\mathrm{H}_{3} \mathrm{O}^{+}\right]}{\left(K_{\mathrm{a}}+\left[\mathrm{H}_{3} \mathrm{O}^{+}\right]\right)^{2}}
$$


Table I. Composition and Physicochemical Properties of $0.7 \% \mathrm{HCl}$, SGFsp, Blank FaSSGF, and Blank FeSSGF

\begin{tabular}{|c|c|c|c|c|}
\hline & $0.7 \% \mathrm{HCl}$ & SGFsp & Blank FaSSGF & Blank FeSSGF \\
\hline \multicolumn{5}{|l|}{ Composition } \\
\hline $\mathrm{HCl}, 37 \% w / v(\mathrm{mM})$ & 83.7 & 83.7 & 35.9 & - \\
\hline $\mathrm{CH}_{3} \mathrm{COOH}(\mathrm{mM})$ & - & - & - & 17.1 \\
\hline $\mathrm{CH}_{3} \mathrm{COONa} \cdot 3 \mathrm{H}_{2} \mathrm{O}(\mathrm{mM})$ & - & - & - & 29.8 \\
\hline $\mathrm{NaCl}(\mathrm{mM})$ & - & 34.2 & 34.2 & 237.0 \\
\hline Double-distilled water $(\mathrm{L})$ & 1.0 & 1.0 & 1.0 & 1.0 \\
\hline \multicolumn{5}{|l|}{ Physicochemical properties } \\
\hline $\mathrm{pH}$ & $1.5 \pm 0.1$ & $1.2 \pm 0.1$ & $1.6 \pm 0.1$ & $5.0 \pm 0.1$ \\
\hline Ionic strength $(\mathrm{mol} / \mathrm{L})$ & 0.084 & 0.118 & 0.070 & 0.273 \\
\hline Buffer capacity $(\mathrm{M} / \Delta \mathrm{pH})$ & - & - & - & 0.025 \\
\hline
\end{tabular}

where

$\beta \quad$ Buffer capacity

$C \quad$ Total buffer concentration (sum of the molar concentrations of acid and salt)

$K_{\text {a }} \quad$ Acid dissociation constant

$\left[\mathrm{H}_{3} \mathrm{O}^{+}\right]$Molar concentration of the hydronium ion

\section{Solubility Studies}

The solubility of pure carvedilol was determined in all dissolution media. Briefly, excess amount of carvedilol powder was added to beakers containing $50 \mathrm{~mL}$ of the media. The beakers were placed in a shaking water bath rotating at $50 \mathrm{rpm}$ and maintained at $37 \pm 1^{\circ} \mathrm{C}$. The $\mathrm{pH}$ of the solution was continuously checked using a calibrated $\mathrm{pH}$ meter (Mettler Toledo, USA) and adjusted, if necessary, to the original $\mathrm{pH}$ of the tested medium. A 5-mL sample was withdrawn after $1,2,4,6$, and $24 \mathrm{~h}$. The samples were centrifuged at $3500 \mathrm{rpm}$ for $15 \mathrm{~min}$ and the supernatant was diluted appropriately with the tested medium. The concentration of carvedilol in each sample was determined using UV spectrophotometry (Varian, Cary 50 UV/VIS spectrophotometer, USA) at $285 \mathrm{~nm}$ using a standard calibration curve of carvedilol prepared using the tested medium. The solubility of carvedilol in each medium was performed at least in triplicate with a standard deviation (SD) less than $10 \%$. The ratio of solubility $\left(C_{\mathrm{S}}\right)$ to drug concentration $\left(C_{\mathrm{D}}\right)$, expressed as $C_{\mathrm{S}} /$ $C_{\mathrm{D}}$, was calculated to represent the sink condition ( $S$ value). According to USP, an $S$ value $>3$ is considered as sink condition (26). The percentage of carvedilol in the ionized form at various $\mathrm{pH}$ values was calculated based on HendersonHasselbalch using Eq. (3) (27).

$\%$ Ionized $=\frac{100}{1+\operatorname{antilog}\left(\mathrm{pH}-\mathrm{p} K_{\mathrm{a}}\right)}$

where

$\mathrm{pH} \quad \mathrm{pH}$ value of the dissolution medium

$\mathrm{p} K_{\mathrm{a}}$ Negative logarithm of the dissociation constant $\left(K_{\mathrm{a}}\right)$ of carvedilol

\section{Estimation of Carvedilol in Dilatrend ${ }^{\circledR}$ Tablets}

The assay of carvedilol was determined using UV-VIS spectrophotometry. Briefly, ten tablets were crushed and a powder mass equivalent to $25 \mathrm{mg}$ carvedilol was transferred to a volumetric flask of $100 \mathrm{~mL}$. Ten milliliters of doubledistilled water, then $70 \mathrm{~mL}$ of methanol and $1 \mathrm{M} \mathrm{HCl} \mathrm{(9:1}$ $v / v$ ) were added to the flask. The flask was placed in a sonicator for $30 \mathrm{~min}$. The volume was completed up to $100 \mathrm{~mL}$ using methanol and $1 \mathrm{M} \mathrm{HCl}(9: 1 v / v)$. The sample was

Table II. Composition and Physicochemical Properties of Acetate Buffer, Blank FeSSIF, Blank FaSSIF, SIFsp, and 0.05 M Phosphate Buffer

\begin{tabular}{|c|c|c|c|c|c|}
\hline & Acetate Buffer & Blank FeSSIF & Blank FaSSIF & SIFsp & $\begin{array}{l}0.05 \text { M Phosphate } \\
\text { Buffer }\end{array}$ \\
\hline \multicolumn{6}{|l|}{ Composition } \\
\hline $\mathrm{KH}_{2} \mathrm{PO}_{4}(\mathrm{mM})$ & - & - & - & 50.0 & 25 \\
\hline $\mathrm{Na}_{2} \mathrm{HPO}_{4}(\mathrm{mM})$ & - & - & 28.4 & - & 25 \\
\hline $\mathrm{NaOH}(\mathrm{mM})$ & - & 101.0 & 8.7 & 22.4 & - \\
\hline $\mathrm{CH}_{3} \mathrm{COOH}(\mathrm{mM})$ & 28.0 & 144.1 & - & - & - \\
\hline $\mathrm{NaCl}(\mathrm{mM})$ & - & 203.2 & 105.9 & - & - \\
\hline $\mathrm{CH}_{3} \mathrm{COONa} \cdot 3 \mathrm{H}_{2} \mathrm{O}(\mathrm{mM})$ & 36.5 & - & - & - & - \\
\hline Double-distilled water (L) & 1.0 & 1.0 & 1.0 & 1.0 & 1.0 \\
\hline \multicolumn{6}{|l|}{ Physicochemical properties } \\
\hline $\mathrm{pH}$ & $4.5 \pm 0.1$ & $5.0 \pm 0.1$ & $6.5 \pm 0.1$ & $6.8 \pm 0.1$ & $6.8 \pm 0.1$ \\
\hline Ionic strength $(\mathrm{mol} / \mathrm{L})$ & 0.037 & 0.304 & 0.200 & 0.072 & 0.100 \\
\hline Buffer capacity $(\mathrm{M} / \Delta \mathrm{pH})$ & 0.034 & 0.130 & 0.120 & 0.034 & 0.023 \\
\hline
\end{tabular}


Table III. Composition and Physicochemical Properties of Phosphate Buffers of pH 6.8 of Various Concentrations $(6.25,12.5,25,50$, and 100 mM)

\begin{tabular}{|c|c|c|c|c|c|}
\hline & $6.25 \mathrm{mM}$ & $12.5 \mathrm{mM}$ & $25 \mathrm{mM}$ & $50 \mathrm{mM}$ & $100 \mathrm{mM}$ \\
\hline \multicolumn{6}{|l|}{ Composition } \\
\hline $\mathrm{Na}_{2} \mathrm{HPO}_{4}(\mathrm{mM})$ & 3.13 & 6.25 & 12.50 & 25.00 & 50.00 \\
\hline $\mathrm{NaH}_{2} \mathrm{PO}_{4}(\mathrm{mM})$ & 3.13 & 6.25 & 12.50 & 25.00 & 50.00 \\
\hline Double-distilled water (L) & 1.00 & 1.00 & 1.00 & 1.00 & 1.00 \\
\hline \multicolumn{6}{|l|}{ Physicochemical properties } \\
\hline $\mathrm{pH}$ & $6.8 \pm 0.1$ & $6.8 \pm 0.1$ & $6.8 \pm 0.1$ & $6.8 \pm 0.1$ & $6.8 \pm 0.1$ \\
\hline Ionic strength $(\mathrm{mol} / \mathrm{L})$ & 0.013 & 0.025 & 0.050 & 0.100 & 0.200 \\
\hline Buffer capacity $(\mathrm{M} / \Delta \mathrm{pH})$ & 0.003 & 0.006 & 0.012 & 0.024 & 0.047 \\
\hline
\end{tabular}

centrifuged at $3500 \mathrm{rpm}$ for $15 \mathrm{~min}$, and the supernatant was diluted appropriately with methanol and $1 \mathrm{M} \mathrm{HCl}(9: 1 \mathrm{v} / \mathrm{v})$. The concentration of carvedilol in each sample was determined using UV spectrophotometry (Varian, Cary $50 \mathrm{UV} /$ VIS spectrophotometer, USA) at $285 \mathrm{~nm}$ using a standard calibration curve of carvedilol prepared in methanol and $1 \mathrm{M}$ $\mathrm{HCl}(9: 1 v / v)$. The uniformity of dosage units of Dilatrend ${ }^{\circledR}$ was performed in triplicate. The uniformity of Dilatrend ${ }^{\circledR}$ tablets has been demonstrated by weight variation.

\section{Dissolution Studies}

Dissolution tests were performed using a calibrated USP apparatus type II (Varian, VK 7000) fitted with an autosampling station consisting of a VK810 peristaltic pump and a VK750 digitally controlled heater/circulator. The dissolution apparatus was connected to a UV spectrophotometer (Cary 50, UVVIS spectrophotometer). Paddles were rotating at $50 \mathrm{rpm}$. Dissolution was performed using $900 \mathrm{~mL}$ of dissolution medium, maintained at $37 \pm 0.5^{\circ} \mathrm{C}$. Samples were taken automatically at 5 , $10,15,30,45,60,75,90,105,120,150,180,210$, and $240 \mathrm{~min}$ and passed through a $45-\mu \mathrm{m}$ polyethylene filter (SUN-SRi, Rockwood, TN, USA). The sample volume was $15 \mathrm{~mL}$, sufficiently enough to flush the filter before making the UV measurement. However, to evaluate carvedilol adsorption to polyethylene filters, a dissolution test of carvedilol powder in $0.7 \% \mathrm{HCl}$ dissolution medium (USP 38, pH 1.45) was performed at a concentration similar to that found in Dilatrend ${ }^{\circledR}$ tablets and under similar dissolution conditions of those of Dilatrend ${ }^{\circledR}$ tablets. Filter tips were securely fitted at the end of the cannulas of three dissolution vessels, and the other three vessels were kept without filters. The UV absorption of filtered and unfiltered carvedilol solutions was measured at different time intervals. No significant loss of

Table IV. Composition and Physicochemical Properties of Phosphate Buffers pH 7.2 and 7.8

\begin{tabular}{lll}
\hline & $\begin{array}{l}\text { Phosphate } \\
\text { Buffer } \mathrm{pH} 7.2\end{array}$ & $\begin{array}{l}\text { Phosphate } \\
\text { Buffer pH 7.8 }\end{array}$ \\
\hline Composition & & \\
$\mathrm{NaH}_{2} \mathrm{PO}_{4}(\mathrm{mM})$ & 28.0 & 8.5 \\
$\mathrm{Na}_{2} \mathrm{HPO}_{4}(\mathrm{mM})$ & 72.0 & 91.5 \\
Double-distilled water $(\mathrm{L})$ & 1.0 & 1.0 \\
Physicochemical properties & & \\
pH & $7.2 \pm 0.1$ & $7.8 \pm 0.1$ \\
Ionic strength (mol/L) & 0.244 & 0.283 \\
Buffer capacity $(\mathrm{M} / \Delta \mathrm{pH})$ & 0.058 & 0.037 \\
\hline
\end{tabular}

carvedilol was observed after filtration and the carvedilol recovery was $>99.0 \%$. The auto-sampling system pulls the sample into the flow cell, measures the absorbance of the sample, and then returns it to the vessel. Thus, no correction was made for the drug quantity removed during sample and no replacement of sample volume was needed. The absorbance was measured at $285 \mathrm{~nm}$. To evaluate tablet excipient interference, a blend of table excipients consisting of sucrose, lactose, povidone, crospovidone, colloidal silicone dioxide, and magnesium stearate (Data Sheet, Dilatrend $^{\circledR}$, Roche) included in the Dilatrend ${ }^{\circledR}$ tablets was prepared. The dissolution test for tablet excipients $(n=6)$ was performed in $0.7 \% \mathrm{HCl}$ dissolution medium (USP 38, $\mathrm{pH} 1.45$ ) at concentrations similar to those found in Dilatrend ${ }^{\circledR}$ tablets and under similar dissolution conditions as those of Dilatrend ${ }^{\circledR}$ tablets. The absorbance of the excipient samples at $285 \mathrm{~nm}$ was reported to be zero, indicating no excipient interference. The amount of carvedilol released from Dilatrend ${ }^{\circledR}$ immediaterelease tablets was calculated against standard calibration curves of carvedilol in each dissolution medium, and the percentage of carvedilol released versus time profiles were constructed. The $\mathrm{pH}$ of the dissolution media in each vessel was continuously monitored and recorded throughout the dissolution experiments. The difference in dissolution profiles was compared using the similarity factor $\left(f_{2}\right)$ calculated using Eq. (4) (28).

$$
f_{2}=50 \times \log \left\{\left[1+(1 / n) \sum_{j=1}^{n}\left(R_{j}-T_{j}\right)^{2}\right]^{-0.5} \times 100\right\}
$$

where

$n \quad$ Number of sampling points

$R_{j}, T_{j}$ Percent of the reference and test products dissolved at time point $j$, respectively

If the $f_{2}$ value was less than 50 , then the dissolution profiles were considered significantly different. If $f_{2}$ was between 50 and 100, the dissolution profiles were considered similar.

\section{RESULTS AND DISCUSSION}

\section{Solubility Studies}

Carvedilol exhibits a high percentage of ionization along the physiological $\mathrm{pH}$ range of GI fluids ranging from 50 to 
$100 \%$ (Table V). The high percentage of ionized carvedilol (protonated free base) suggests the formation of salts with the anion of buffer systems, which may affect the solubility product of the weakly basic drug $(10,11,29)$. Therefore, the selection of the anion of the buffer system (buffer species) may be important for the in vitro dissolution studies of carvedilol. As shown in Fig. 1, the NH group of carbazole in carvedilol is acidic of $\mathrm{p} K_{\mathrm{a}}$ of 15.0 (calculated using ChemAxon software) because the lone pair of electrons is involved in aromatization. Thus, the $\mathrm{N}-\mathrm{H}$ bond of carbazole is weak; hydrogen is easily hydrolyzed as $\mathrm{H}^{+}$(acidic proton). Contrarily, the aliphatic secondary amine is weakly basic of $\mathrm{p} K_{\mathrm{a}}=7.8$ (6) due to the electronegativity of the surrounding oxygen atoms and the bulkiness of attached alkyl groups harboring aromatic rings on two wings. Interestingly, the amphoteric characteristic (having both acidic and basic moieties) of carvedilol describes its ionization pattern. In acidic $\mathrm{pH}$ medium, the aliphatic $\mathrm{NH}$ is ionized forming a cationic center, whereas in basic $\mathrm{pH}$ medium, the carbazole $\mathrm{NH}$ is ionized forming an anionic center. Therefore, harboring a zwitterion characteristic demonstrates its solubility manner.

Carvedilol drug substance (solid state) is stable when exposed to heat $\left(80^{\circ} \mathrm{C}\right.$ for 14 days), heat and relative humidity (RH) $\left(40^{\circ} \mathrm{C}\right.$ and $75 \% \mathrm{RH}$ for 14 days), and UV-VIS light $\left(1.3 \times 10^{6} \mathrm{~lx} \mathrm{~h}\right)$. Degradation products were found to be less than $0.05 \%$ under these conditions. In addition, it has been shown that carvedilol solution is stable in acidic $(0.1 \mathrm{~N} \mathrm{HCl}$, $60^{\circ} \mathrm{C}$ for $\left.4 \mathrm{~h}\right)$, basic $\left(0.1 \mathrm{~N} \mathrm{NaOH}, 60^{\circ} \mathrm{C}\right.$ for $\left.4 \mathrm{~h}\right)$, UV-VIS light $\left(1.3 \times 10^{6} \mathrm{~lx} \mathrm{~h}\right.$, water $)$, and heat $\left(60^{\circ} \mathrm{C}\right.$, water for $\left.4 \mathrm{~h}\right)$, where no individual degradation product $>0.06 \%$ was generated under these stress conditions (30). In another study (31), no significant degradation products were observed after exposure of carvedilol, both as solid state and methanolic solutions, to acid (1 $\mathrm{N} \mathrm{HCl}$ solution, $90^{\circ} \mathrm{C}$ for $6 \mathrm{~h}$ ), neutral (water, $90^{\circ} \mathrm{C}$ for $6 \mathrm{~h}$ ), and photolytic (UVC-254 nm 30-W lamp, $25^{\circ} \mathrm{C}$ for 7 days) conditions, carried out according to ICH guideline Q1A (R2). However, gradual degradation was observed in basic conditions $\left(1 \mathrm{~N} \mathrm{NaOH}, 90^{\circ} \mathrm{C}\right.$ for $\left.6 \mathrm{~h}\right)$.

Several studies used the same experimental method that was used in this work for assessing the solubility of carvedilol in different dissolution media (hydrochloric acid solution, $\mathrm{pH}$ 1.2; acid phthalate buffer, $\mathrm{pH} 3.0$; acetate buffer, $\mathrm{pH} 4.5$; and phosphate buffers, $\mathrm{pH} 5.8,6.8,7.4)$ and in water at $37 \pm 0.5^{\circ} \mathrm{C}$ until equilibrium was reached for 24 or $48 \mathrm{~h}$ (32-34). Samples were not protected from light during solubility analysis. The

Table V. Percentage of Ionized and Unionized Carvedilol $\left(\mathrm{p} K_{\mathrm{a}} 7.8\right)$ at Various pH Values Calculated Using Eq. (3)

\begin{tabular}{lll}
\hline $\mathrm{pH}$ & $\begin{array}{l}\text { Ionized } \\
\text { carvedilol (\%) }\end{array}$ & $\begin{array}{l}\text { Unionized } \\
\text { carvedilol (\%) }\end{array}$ \\
\hline 1.2 & 100 & 0 \\
1.45 & 100 & 0 \\
1.6 & 100 & 0 \\
4.5 & 99.95 & 0.05 \\
5.0 & 99.84 & 0.16 \\
6.5 & 95.23 & 4.77 \\
6.8 & 90.91 & 9.09 \\
7.2 & 79.92 & 20.08 \\
7.8 & 50 & 50 \\
\hline
\end{tabular}

solid phase of the in situ salt formed during the solubility studies was not identified in this work.

The saturation solubility of carvedilol in all dissolution media is given in Table VI. Carvedilol with a $\mathrm{p} K_{\mathrm{a}}$ of 7.8 exhibits the typical $\mathrm{pH}$-dependent solubility profile of a weak base with a high solubility in dissolution media of low $\mathrm{pH}$, and low solubility in the dissolution media of high $\mathrm{pH}$. It is worth noting that the saturation solubility of carvedilol was achieved within $1 \mathrm{~h}$ in the acidic media $(\mathrm{pH} 1.2-5.0)$. However, in the basic media ( $\mathrm{pH}$ 6.5-7.8), the saturation solubility of carvedilol was achieved after $24 \mathrm{~h}$. At pH 6.8, the solubility of carvedilol in phosphate buffers 25,50 , and $100 \mathrm{mM}$ was $~ 37 \%$ less compared to phosphate buffers 6.25 and $12.5 \mathrm{mM}$. Lower solubility of carvedilol in buffers at high salt concentrations might be related to the higher ionic strength values of the dissolution media, where it has been shown that solubility decreases with an increase in ionic strength $(35,36)$. Furthermore, although more than $90 \%$ of carvedilol was in its protonated form at $\mathrm{pH} 6.8$ (Table V), the formation of the less soluble carvedilol phosphate salt, as reported by Loftsson (10), significantly reduces the solubility of carvedilol in these dissolution media. Carvedilol shows a very low solubility at $\mathrm{pH}$ 7.2. At $\mathrm{pH} 7.8$, the solubility dropped by $90 \%$ compared to its solubility at $\mathrm{pH}$ 6.8. The solubility of carvedilol in doubledistilled water of zero ionic strength and zero buffer capacity was also reduced by $\sim 45 \%$ compared to its solubility at $\mathrm{pH} 6.8$.

Therefore, our solubility studies illustrate that carvedilol is more soluble in acidic media. This means that the basicity of the aliphatic NH, rather than the acidity of the carbazole $\mathrm{NH}$, accounts for its solubility. Thus, the basic strength of the aliphatic NH is higher than the acidic strength of the carbazole $\mathrm{NH}$ and consequently drives its solubility in acetate buffer $(\mathrm{pH}$ 4.5). Surprisingly, the solubility in acidic media is preferred particularly at $\mathrm{pH} 1.6$ and 4.5 in fasting condition. The higher $\mathrm{pH}$ led to a decrease in solubility, as shown in $\mathrm{pH} 6.8$

Table VI. Saturation Solubility $\left(C_{\mathrm{S}}\right)$ and Relative Sink Conditions ( $S$ Value) of Carvedilol in Dissolution Media. Data are Presented as the Mean \pm SD $(n=3)$

\begin{tabular}{lccc}
\hline Dissolution media & $\mathrm{pH}$ & $\begin{array}{l}\text { Solubility } \\
\left(C_{\mathrm{S}}, \mu \mathrm{g} / \mathrm{mL}\right)\end{array}$ & $\begin{array}{c}S \text { value } \\
\left(C_{\mathrm{S}} / C_{\mathrm{D}}{ }^{a}\right)\end{array}$ \\
\hline $0.7 \% \mathrm{HCl}$ & 1.45 & $545.1 \pm 5.0$ & 19.6 \\
SGFsp & 1.2 & $832.0 \pm 66.0$ & 29.9 \\
Blank FaSSGF & 1.6 & $2398.6 \pm 40.9$ & 86.3 \\
Blank FeSSGF & 5.0 & $995.6 \pm 20.5$ & 35.8 \\
Acetate buffer & 4.5 & $2591.4 \pm 35.8$ & 93.2 \\
Blank FaSSIF & 6.5 & $51.6 \pm 5.5$ & 1.9 \\
Blank FeSSIF & 5.0 & $830.7 \pm 17.4$ & 29.9 \\
SIFsp & 6.8 & $51.1 \pm 3.0$ & 1.8 \\
Phosphate buffer (IntPh3) & 6.8 & $51.9 \pm 5.8$ & 1.9 \\
Phosphate buffer 6.25 mM & 6.8 & $52.5 \pm 4.2$ & 1.9 \\
Phosphate buffer 12.5 mM & 6.8 & $53.5 \pm 1.1$ & 1.9 \\
Phosphate buffer 25 mM & 6.8 & $31.8 \pm 1.9$ & 1.1 \\
Phosphate buffer 50 mM & 6.8 & $31.5 \pm 1.0$ & 1.1 \\
Phosphate buffer 100 mM & 6.8 & $34.3 \pm 0.7$ & 1.2 \\
Phosphate buffer 100 mM & 7.2 & $19.1 \pm 1.5$ & 0.7 \\
Phosphate buffer 100 mM & 7.8 & $5.8 \pm 0.5$ & 0.2 \\
Double-distilled water & 6.5 & $27.9 \pm 3.9$ & 1.0 \\
\hline
\end{tabular}

${ }^{a} C_{\mathrm{D}}=27.8 \mu \mathrm{g} / \mathrm{mL}$ 
phosphate buffers. Altogether, the acidic $\mathrm{pH}$ medium is preferred for complete solubility of carvedilol.

The calculated solubility $\left(C_{\mathrm{S}}\right)$ to dose $\left(C_{\mathrm{D}}\right)$ ratio $(S$ value $)$ for carvedilol resulted in values $>3$ in all acidic media, which indicates that they provided sink conditions. However, the $S$ value was $<3$ in the basic media, indicating no sink condition (Table VI). The poor solubility of carvedilol in the small intestine with no sink condition could account for the precipitation of carvedilol in the small intestine.

\section{Carvedilol Content in Dilatrend ${ }^{\circledR}$ Tablets}

Carvedilol content in Dilatrend ${ }^{\circledR}$ tablets was $99.7 \pm 2.2 \%$ $(n=3)$, and the uniformity of Dilatrend ${ }^{\circledR}$ tablets was between 98.5 and $100.5 \%(n=10)$.

\section{Dissolution Studies}

As shown in Fig. 2, the rate of release of carvedilol from Dilatrend ${ }^{\circledR}$ tablets in acidic dissolution media $(0.7 \% \mathrm{HCl}$, SGFsp, blank FaSSGF, and blank FeSSGF) was rapid and nearly superimposable $\left(f_{2}>50\right)$ due to their low $\mathrm{pH}$. Dissolution results were also consistent with carvedilol solubility data (Table VI). Therefore, carvedilol is expected to dissolve quickly and completely in both the fasted- and fedstate conditions of the stomach.

Carvedilol release was complete and approached a plateau level within $60 \mathrm{~min}$, achieving an average of 95.8, 97.2, 97.4, and $98.2 \%$ in $0.7 \% \mathrm{HCl}$, SGFsp, blank FaSSGF, and blank FeSSGF, respectively. Although blank FeSSGF exhibited higher $\mathrm{pH}$ values compared to $0.7 \% \mathrm{HCl}$, SGFsp, and blank FaSSGF (5.0 vs. 1.5, 1.2, and 1.6, respectively), the dissolution of carvedilol was complete. This might be attributed to the presence of acetate buffer in blank FeSSGF, which forms a water-soluble acetate salt (10). Due to the low $\mathrm{pH}$ value of the dissolution media, the influence of ionic strength and buffer capacity was not prominent, indicating the important role of $\mathrm{pH}$ in determining the percentage of carvedilol released in acidic media.

The buffer composition of the dissolution media can nonetheless have an effect on the dissolution of drugs as seen with blank FeSSGF, where the presence of acetate enhances

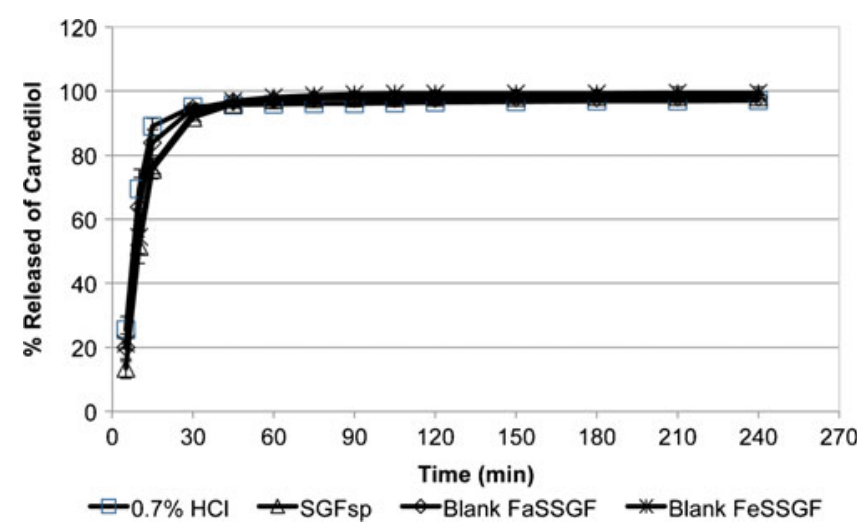

Fig. 2. Dissolution profiles of carvedilol from Dilatrend ${ }^{\circledR}$ tablets in $0.7 \% \mathrm{HCl}(\mathrm{pH} 1.45, n=6)$, SGFsp ( $\mathrm{pH} 1.2, n=6)$, blank FaSSGF $(\mathrm{pH}$ 1.6, $n=6$ ), and blank FeSSGF (pH 5.0, $n=6$ ). Data are represented as the mean \pm SD the dissolution rate. As shown in Fig. 3, the rate of carvedilol release in acetate buffer was fast, with $\sim 39.2 \%$ of carvedilol released within $5 \mathrm{~min}$ and almost completely dissolved $(97.4 \%)$ within the first $15 \mathrm{~min}$. In acetate buffer ( $\mathrm{pH} \mathrm{4.5),}$ 99.95\% of carvedilol is in its protonated form (Table V). Loftsson et al. (10) have reported that the protonated base would form a water-soluble salt with the anionic form of acetic acid, resulting in increased dissolution. Therefore, the dissolution rate of carvedilol was clearly dependent on $\mathrm{pH}$ and buffer species of the dissolution media.

When comparing the dissolution profiles of blank FaSSIF ( $\mathrm{pH}$ 6.5) and blank FeSSIF ( $\mathrm{pH} 5.0$ ), the dissolution rate in blank FeSSIF was significantly faster $\left(f_{2}=39.7\right)$. After $240 \mathrm{~min}$, however, the percentage of carvedilol released was equal $(\sim 86 \%)$ in both media. The increase in the dissolution rate of carvedilol in blank FeSSIF can be explained by the lower $\mathrm{pH}$ value of this medium compared to the blank FaSSIF (5.0 vs. 6.5). In addition, the presence of acetate buffer in blank FeSSIF would enhance carvedilol dissolution as has been reported by Loftsson et al. (10). Unlike blank FaSSIF, the presence of $\mathrm{NaCl}$ and phosphate species resulted in the formation of the less soluble hydrochloride and phosphate carvedilol salts, thus reducing the rate of carvedilol dissolution in blank FaSSIF (10).

In simulated intestinal fluids, the amount of carvedilol released was significantly reduced to 70.2 and $70.0 \%$ in the dissolution media SIFsp and $0.05 \mathrm{M}$ phosphate buffer (IntPh3), respectively. The dissolution profiles of carvedilol in SIFsp and $0.05 \mathrm{M}$ phosphate buffer (IntPh3) were superimposable $\left(f_{2}>50\right)$, indicating that the difference in the species composition of the two buffers $\left(\mathrm{KH}_{2} \mathrm{PO}_{4}\right.$ and $\mathrm{NaOH}$ in SIFsp vs. $\mathrm{KH}_{2} \mathrm{PO}_{4}$ and $\mathrm{Na}_{2} \mathrm{HPO}_{4}$ in $0.05 \mathrm{M}$ phosphate buffer (IntPh3) had no influence on the rate of carvedilol release. Since the $\mathrm{pH}$ and ionic strength of the two buffers were equivalent (Table II), dissolution profiles were found to be similar. Although the buffer capacity of the $0.05 \mathrm{M}$ phosphate buffer (IntPh3) was slightly higher than that of SIFsp, no difference in the dissolution profiles was observed. This is consistent with a previous study by Dressman et al. who found

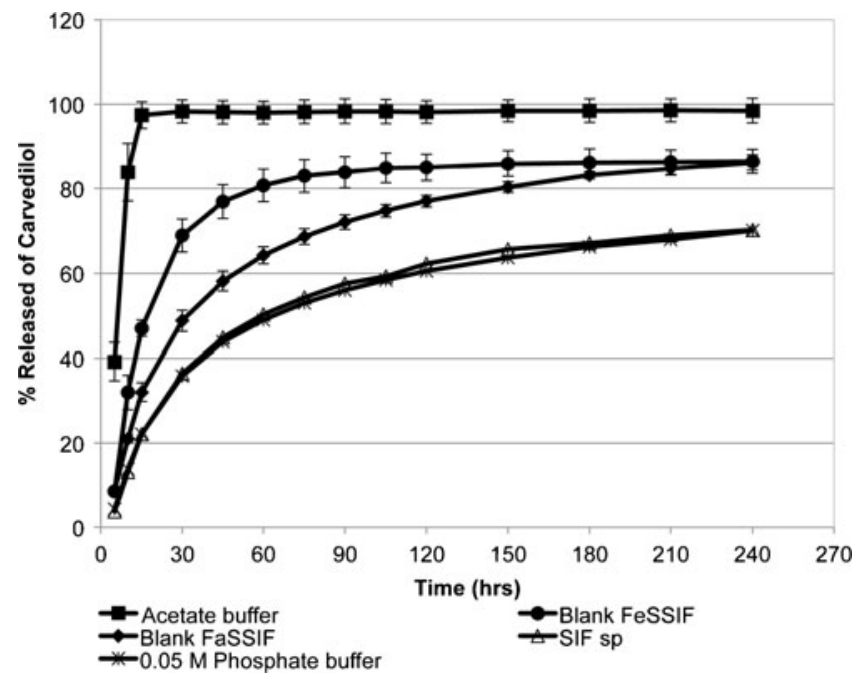

Fig. 3. Dissolution profiles of carvedilol from Dilatrend ${ }^{\circledR}$ tablets in acetate buffer ( $\mathrm{pH} 4.5, n=6)$, blank FeSSIF ( $\mathrm{pH} 5.0, n=4)$, blank FaSSIF (pH 6.5, $n=3$ ), SIFsp (pH 6.8, $n=3$ ), and $0.05 \mathrm{M}$ phosphate buffer $(\mathrm{pH} 6.8, n=3)$. Data are represented as the mean \pm SD 
that SIFsp could be used interchangeably with $0.05 \mathrm{M}$ phosphate buffer (IntPh3) in the dissolution testing of immediaterelease dosage forms (37). Overall, acetate buffer and blank FeSSIF allowed for higher dissolution rate than blank FaSSIF, SIFsp, and 0.05 M phosphate buffer (IntPh3).

In general, while weak bases exhibit high dissolution rate in the stomach, they tend to supersaturate and precipitate when entering the small intestine. For carvedilol, less precipitation is expected in the duodenum and fed-state intestinal fluid as apparent from the dissolution results of carvedilol in acetate buffer pH 4.5 and blank FeSSIF. Nonetheless, SIFsp and $0.05 \mathrm{M}$ phosphate buffer (IntPh3) remain commonly used as compendial dissolution media $(7,11,38-42)$.

To better understand the dissolution behavior of carvedilol in the intestinal fluid and to adequately predict its precipitation upon entry into the small intestine, the dissolution of carvedilol tablets in phosphate buffers of different ionic strengths and buffer capacities was tested. Figure 4 a compares the dissolution profiles of carvedilol from Dilatrend ${ }^{\circledR}$ tablets in phosphate buffers ( $\mathrm{pH}$ 6.8) of different buffer concentrations $(6.25,12.5,25,50$, and $100 \mathrm{mM})$. Phosphate buffers vary in their ionic strengths and buffer capacities (Table III). The dissolution profile of carvedilol in double-distilled water of zero ionic strength and zero buffer capacity was used as a reference. The ionic strength of phosphate buffers ranged from 0.013 to $0.200 \mathrm{~mol} / \mathrm{L}$, which covers the typical values of

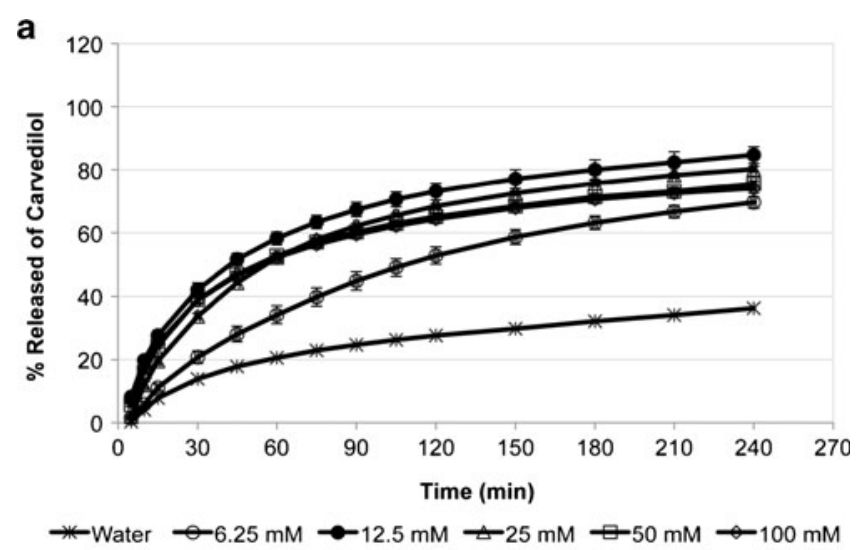

b

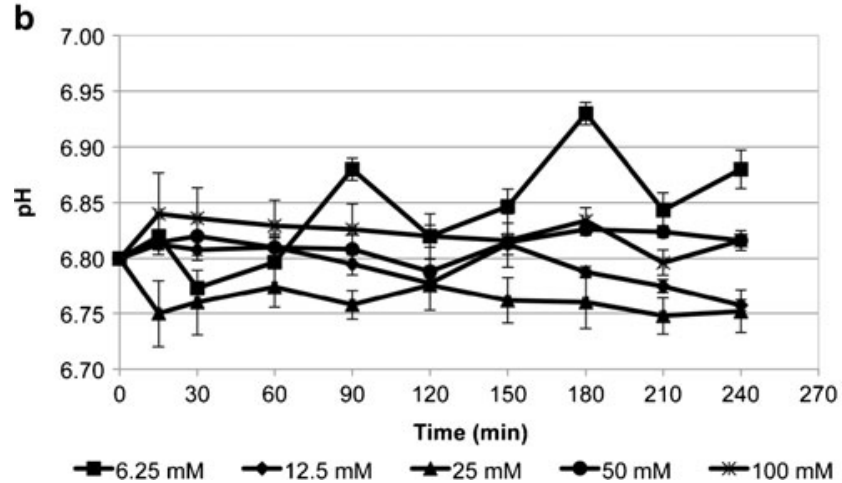

Fig. 4. a Dissolution profiles of carvedilol from Dilatrend ${ }^{\circledR}$ tablets in phosphate buffers of $\mathrm{pH} 6.8$ of various concentrations $(6.25,12.5,25$, 50 , and $100 \mathrm{mM}$ ), and in double-distilled water. Data are represented as the mean $\pm \mathrm{SD}(n=5)$. b $\mathrm{pH}$ profiles during dissolution studies of carvedilol from Dilatrend ${ }^{\circledR}$ tablets in phosphate buffers of pH 6.8 of various concentrations $(6.25,12.5,25,50$, and $100 \mathrm{mM})$. Data are represented as the mean $\pm \mathrm{SD}(n=5)$ ionic strength of the human intestinal fluid $(0.070-0.166 \mathrm{~mol} / \mathrm{L})$ (17). Similarly, the buffer capacity of the phosphate buffers ranged from 0.003 to $0.047 \mathrm{M} / \Delta \mathrm{pH}$, which approximates the buffer capacity of the human intestinal fluid $(0.003-0.030 \mathrm{M} /$ $\Delta \mathrm{pH})(15,18)$.

The rate of carvedilol release was slowest in doubledistilled water with only $36.2 \%$ of carvedilol released at $240 \mathrm{~min}$. Due to the high $\mathrm{pH}$ value of the phosphate buffers ( $\mathrm{pH}$ 6.8), no complete dissolution was observed for carvedilol, where only $69.6,84.7,80.3,75.5$, and $74.1 \%$ of carvedilol was released in $6.25,12.5,25,50$, and $100 \mathrm{mM}$ buffers, respectively. Of the buffers, carvedilol release was lowest in $6.25 \mathrm{mM}$ phosphate buffer (69.6\% after $240 \mathrm{~min})$. The dissolution profile of carvedilol in $6.25 \mathrm{mM}$ was significantly different from its dissolution in $12.5,25,50$, and $100 \mathrm{mM}\left(f_{2}<50\right)$. This might be due to the low buffer capacity of the $6.25 \mathrm{mM}$ phosphate buffer $(0.003 \mathrm{M} / \Delta \mathrm{pH})$. It has been found that lowering the buffer capacity of the dissolution media decreased drug solubility and hence the dissolution rate $(43,44)$.

When the ionic strength increased in phosphate buffers $12.5,25,50$, and $100 \mathrm{mM}$, the amount of drug released was slightly decreased in the order $12.5 \mathrm{mM}(84.7 \%), 25 \mathrm{mM}$ (80.3\%), $50 \mathrm{mM}(75.5 \%)$, and $100 \mathrm{mM}$ (74.1\%), after $240 \mathrm{~min}$. Nonetheless, no significant difference was observed in their dissolution profiles $\left(f_{2}>50\right)$. These results were in agreement with Kincl et al. who studied the rate of diclofenac release from lipophilic matrix tablets in phosphate buffers with various ionic strengths (36). Kincl et al. found that the rate of diclofenac release decreased with increasing ionic strength. However, there was no significant difference between drug release profiles in phosphate buffers with high ionic strength $(0.14-0.51 \mathrm{~mol} / \mathrm{L})$. The dissolution data were also in agreement with the solubility results. The almost equal solubilities of carvedilol in phosphate buffers 25, 50, and $100 \mathrm{mM}$ seem to be consistent with their dissolution profiles, where no significant difference was observed in carvedilol dissolution behavior $\left(f_{2}>50\right)$. Despite equal solubility of carvedilol in phosphate buffers 6.25 and $12.5 \mathrm{mM}$, carvedilol exhibited higher dissolution rate in $12.5 \mathrm{mM}$ than $6.25 \mathrm{mM}$. This might be attributed to the relatively higher buffer capacity of $12.5 \mathrm{mM}$ compared to $6.25 \mathrm{mM}$. No significant difference

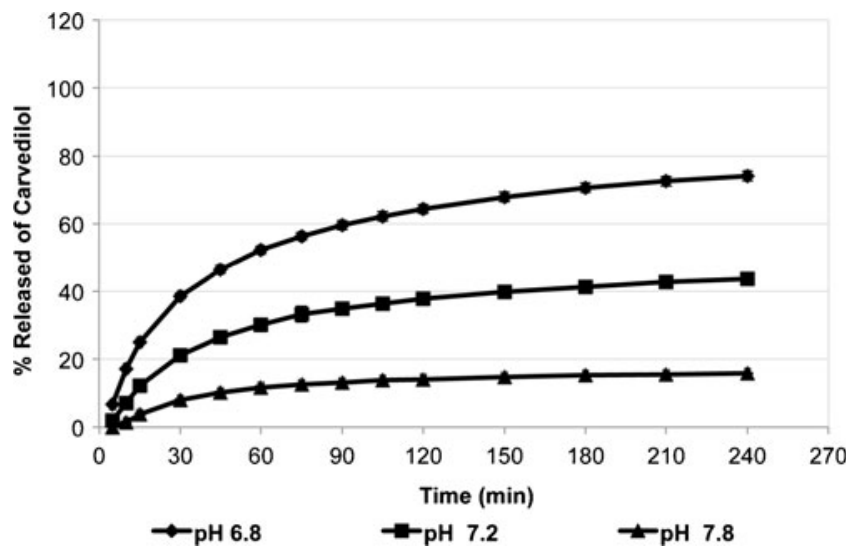

Fig. 5. Dissolution profiles of carvedilol from Dilatrend ${ }^{\circledR}$ tablets in phosphate buffers $100 \mathrm{mM}$ of $\mathrm{pH} 7.2(n=3)$ and $\mathrm{pH} 7.8(n=3)$. The dissolution profile of carvedilol in phosphate buffer $100 \mathrm{mM}$ of $\mathrm{pH} 6.8$ $(n=5)$ was added to the figure for comparison. Data are represented as the mean $\pm \mathrm{SD}$ 
was observed $\left(f_{2}>50\right)$ in the dissolution profiles of carvedilol in phosphate buffers 12.5, 25, 50, and $100 \mathrm{mM}$; SIFsp; and $0.05 \mathrm{M}$ phosphate buffer (IntPh3).

To confirm that the buffer capacity of the phosphate buffers, particularly those of low concentrations $(6.25,12.5$, and $25 \mathrm{mM}$ ), was maintained throughout the dissolution experiment, the $\mathrm{pH}$ of the buffers was measured and is illustrated in Fig. 4b. The results show that the initial $\mathrm{pH}$ value of 6.80 was maintained throughout the dissolution experiments, with a maximum deviation of $\pm 0.05 \mathrm{pH}$ units/min from the initial $\mathrm{pH}$ value. Therefore, the results of the $\mathrm{pH}$ measurements confirm that phosphate buffers 12.5, 25, 50, and $100 \mathrm{mM}$ maintained their buffer capacities. In phosphate buffer $6.25 \mathrm{mM}$, pH values deviated from the initial $\mathrm{pH}$ value reaching a maximum value of 6.93 , indicating that the initial $\mathrm{pH}$ value was less precisely maintained throughout the dissolution experiment.

To further investigate the influence of $\mathrm{pH}$ on the rate of carvedilol release, dissolution studies were performed in phosphate buffer $100 \mathrm{mM}$ of $\mathrm{pH} 7.2$ and 7.8. Carvedilol release in these buffers was compared to its release in phosphate buffer $100 \mathrm{mM}$ of $\mathrm{pH} 6.8$ (Fig. 5). At pH 6.8, the maximum amount of carvedilol released was about $74.1 \%$ at $240 \mathrm{~min}$. At $\mathrm{pH} 7.2$, the dissolution rate was slower, where only $43.6 \%$ of carvedilol was released after $240 \mathrm{~min}$. The dissolution rate of carvedilol was slowest at $\mathrm{pH} 7.8$, where only $15.9 \%$ of carvedilol was released after $240 \mathrm{~min}$. These results suggest that carvedilol exhibits poor dissolution in the distal small intestine and colon, making it a poor candidate for controlled-release dosage forms (11). The dissolution results of carvedilol in these media were consistent with their solubility data (Table VI).

\section{CONCLUSIONS}

This work focuses on studying the $\mathrm{pH}$-dependent solubility and dissolution behavior of the weakly basic BCS class II model drug carvedilol which has a $\mathrm{p} K_{\mathrm{a}}$ value of 7.8. The solubility and percentage of carvedilol released in the in vitro dissolution studies were highest in media simulating the gastric fluid with low $\mathrm{pH}$ values. However, in media simulating the intestinal fluid, the solubility and percentage of carvedilol released were reduced dramatically, suggesting precipitation in the small intestine. It is evident that the solubility and dissolution of carvedilol are strongly dependent on $\mathrm{pH}$. Carvedilol solubility and dissolution decreased with increasing ionic strength. Lowering buffer capacity resulted in a decrease in carvedilol solubility and hence dissolution rate. Buffer species significantly influenced the solubility and dissolution rate of carvedilol.

\section{ACKNOWLEDGMENTS}

This project was financially supported by the Deanship of Academic Research and Graduate Studies at Al-Zaytoonah University of Jordan.

\section{REFERENCES}

1. Dressman JB, Amidon GL, Reppas C, Shah VP. Dissolution testing as a prognostic tool for oral drug absorption: immediate release dosage forms. Pharm Res. 1998;15(1):11-22.
2. Galia E, Nicolaides E, Horter D, Lobenberg R, Reppas C, Dressman JB. Evaluation of various dissolution media for predicting in vivo performance of class I and II drugs. Pharm Res. 1998;15(5):698-705.

3. Sheng JJ, Kasim NA, Chandrasekharan R, Amidon GL. Solubilization and dissolution of insoluble weak acid, ketoprofen: effects of $\mathrm{pH}$ combined with surfactant. Eur J Pharm Sci. 2006;29(3-4):306-14.

4. Kostewicz ES, Wunderlich M, Brauns U, Becker R, Bock T, Dressman JB. Predicting the precipitation of poorly soluble weak bases upon entry in the small intestine. J Pharm Pharmacol. 2004;56(1):43-51.

5. Carlert S, Palsson A, Hanisch G, von Corswant C, Nilsson C, Lindfors L, et al. Predicting intestinal precipitation-a case example for a basic BCS class II drug. Pharm Res. 2010;27(10):2119-30.

6. Tsume Y, Mudie DM, Langguth P, Amidon GE, Amidon GL. The Biopharmaceutics Classification System: subclasses for in vivo predictive dissolution (IPD) methodology and IVIVC. Eur J Pharm Sci. 2014;57:152-63.

7. Kukec S, Dreu R, Vrbanec T, Srcic S, Vrecer F. Characterization of agglomerated carvedilol by hot-melt processes in a fluid bed and high shear granulator. Int J Pharm. 2012;430(1-2):74-85.

8. Mahmoud EA, Bendas ER, Mohamed MI. Preparation and evaluation of self-nanoemulsifying tablets of carvedilol. AAPS PharmSciTech. 2009;10(1):183-92.

9. Stillhart C, Duerr D, Kuentz M. Toward an improved understanding of the precipitation behavior of weakly basic drugs from oral lipid-based formulations. J Pharm Sci. 2014;103(4):1194-203.

10. Loftsson T, Vogensen SB, Desbos C, Jansook P. Carvedilol: solubilization and cyclodextrin complexation: a technical note. AAPS PharmSciTech. 2008;9(2):425-30.

11. Planinsek O, Kovacic B, Vrecer F. Carvedilol dissolution improvement by preparation of solid dispersions with porous silica. Int J Pharm. 2011;406(1-2):41-8.

12. Tsume Y, Langguth P, Garcia-Arieta A, Amidon GL. In silico prediction of drug dissolution and absorption with variation in intestinal $\mathrm{pH}$ for BCS class II weak acid drugs: ibuprofen and ketoprofen. Biopharm Drug Dispos. 2012;33(7):366-77.

13. Lindahl A, Ungell AL, Knutson L, Lennernas H. Characterization of fluids from the stomach and proximal jejunum in men and women. Pharm Res. 1997;14(4):497-502.

14. Bergstrom CAS, Holm R, Jorgensen SA, Andersson SBE, Artursson $\mathrm{P}$, Beato S, et al. Early pharmaceutical profiling to predict oral drug absorption: current status and unmet needs. Eur J Pharm Sci. 2014;57:173-99.

15. Kalantzi L, Goumas K, Kalioras V, Abrahamsson B, Dressman JB, Reppas C. Characterization of the human upper gastrointestinal contents under conditions simulating bioavailability/ bioequivalence studies. Pharm Res. 2006;23(1):165-76.

16. Garbacz G, Kolodziej B, Koziolek M, Weitschies W, Klein S. A dynamic system for the simulation of fasting luminal $\mathrm{pH}$-gradients using hydrogen carbonate buffers for dissolution testing of ionisable compounds. Eur J Pharm Sci. 2014;51:224-31.

17. Johnson JL, Holinej J, Williams MD. Influence of ionic-strength on matrix integrity and drug release from hydroxypropyl cellulose compacts. Int J Pharm. 1993;90(2):151-9.

18. Persson EM, Gustafsson AS, Carlsson AS, Nilsson RG, Knutson $\mathrm{L}$, Forsell $\mathrm{P}$, et al. The effects of food on the dissolution of poorly soluble drugs in human and in model small intestinal fluids. Pharm Res. 2005;22(12):2141-51.

19. Vertzoni M, Dressman J, Butler J, Hempenstall J, Reppas C. Simulation of fasting gastric conditions and its importance for the in vivo dissolution of lipophilic compounds. Eur J Pharm Biopharm. 2005;60(3):413-7.

20. Jantratid E, Janssen N, Reppas C, Dressman JB. Dissolution media simulating conditions in the proximal human gastrointestinal tract: an update. Pharm Res. 2008;25(7):1663-76.

21. Arndt M, Chokshi H, Tang K, Parrott NJ, Reppas C, Dressman JB. Dissolution media simulating the proximal canine gastrointestinal tract in the fasted state. Eur J Pharm Biopharm. 2013;84(3):633-41.

22. Klein S, Wempe MF, Zoeller T, Buchanan NL, Lambert JL, Ramsey MG, et al. Improving glyburide solubility and dissolution 
by complexation with hydroxybutenyl-beta-cyclodextrin. J Pharm Pharmacol. 2009;61(1):23-30.

23. Klein S, Rudolph M, Dressman J. Drug release characteristics of different mesalazine products using USP apparatus 3 to simulate passage through the GI tract. Dissolut Technol. 2002;9:6-12.

24. Marques MRC, Loebenberg R, Almukainzi M. Simulated biological fluids with possible application in dissolution testing. Dissolut Technol. 2011;18(3):15-28.

25. Solon K, Flores-Alsina X, Mbarnba CK, Volcke EIP, Tait S, Batstone D, et al. Effects of ionic strength and ion pairing on (plant-wide) modelling of anaerobic digestion. Water Res. 2015;70:235-45.

26. Jamzad S, Fassihi R. Role of surfactant and $\mathrm{pH}$ on dissolution properties of fenofibrate and glipizide- a technical note. AAPS PharmSciTech. 2006;7(2):E33-E.

27. Buffered and isotonic solutions. In: Sinko PJ, editor. Martin's physical pharmacy and pharmaceutical sciences. 6 ed. Philadelphia, PA: Lippincott Williams and Wilkins; 2011. p. 164.

28. Costa P, Manuel J, Lobo S. Modeling and comparison of dissolution profiles. Eur J Pharm Sci. 2001;13(2):123-33.

29. Takacs-Novak K, Szoke V, Voelgyi G, Horvath P, Ambrus R, Szabo-Revesz P. Biorelevant solubility of poorly soluble drugs: rivaroxaban, furosemide, papaverine and niflumic acid. $\mathrm{J}$ Pharmaceut Biomed. 2013;83:279-85.

30. Beattie K, Phadke G, Novakovic J. Carvedilol. Profiles of drug substances, excipients, and related methodology. 2013;38:113-57.

31. Lanzanova FA, Argenta D, Arend MZ, Brum Junior L, Cardoso SG. LC and LC-MS evaluation of stress degradation behavior of carvedilol. J Liq Chromatogr R T. 2009;32(4):526-43.

32. Chakraborty S, Shukla D, Jain A, Mishra B, Singh S. Assessment of solubilization characteristics of different surfactants for carvedilol phosphate as a function of $\mathrm{pH}$. J Colloid Interface Sci. 2009;335(2):242-9.

33. Yuvaraja K, Khanam J. Enhancement of carvedilol solubility by solid dispersion technique using cyclodextrins, water soluble polymers and hydroxyl acid. J Pharmaceut Biomed. 2014;96:10-20.

34. Zhang Y, Zhi Z, Li X, Gao J, Song Y. Carboxylated mesoporous carbon microparticles as new approach to improve the oral bioavailability of poorly water-soluble carvedilol. Int J Pharm. 2013;454(1):403-11.
35. Chahiyan H, Gharib F, Farajtabar A. Thermodynamic studies on solubility and protonation constant of acetaminophen at different ionic strengths and various temperatures. J Mol Liq. 2014;199:137-42.

36. Kincl M, Meleh M, Veber M, Vrecer F. Study of physicochemical parameters affecting the release of diclofenac sodium from lipophilic matrix tablets. Acta Chim Slov. 2004;51(3):409-25.

37. Stippler E, Kopp S, Dressman JB. Comparison of US Pharmacopeia simulated intestinal fluid TS (without pancreatin) and phosphate standard buffer $\mathrm{pH} 6.8$, TS of the international pharmacopoeia with respect to their use in in vitro dissolution testing. Dissolut Technol. 2004;11:6-10.

38. Fadda HM, Merchant HA, Arafat BT, Basit AW. Physiological bicarbonate buffers: stabilisation and use as dissolution media for modified release systems. Int J Pharm. 2009;382(1-2):5660.

39. Piao Z-Z, Choe J-S, Oh KT, Rhee Y-S, Lee B-J. Formulation and in vivo human bioavailability of dissolving tablets containing a self-nanoemulsifying itraconazole solid dispersion without precipitation in simulated gastrointestinal fluid. Eur J Pharm Sci. 2014;51:67-74.

40. Raju V, Murthy KVR. Development and validation of new discriminative dissolution method for carvedilol tablets. Indian J Pharm Sci. 2011;73(5):527-36.

41. Shono Y, Jantratid E, Dressman JB. Precipitation in the small intestine may play a more important role in the in vivo performance of poorly soluble weak bases in the fasted state: case example nelfinavir. Eur J Pharm Biopharm. 2011;79(2):34956.

42. Wagner C, Jantratid E, Kesisoglou F, Vertzoni M, Reppas C, Dressman JB. Predicting the oral absorption of a poorly soluble, poorly permeable weak base using biorelevant dissolution and transfer model tests coupled with a physiologically based pharmacokinetic model. Eur J Pharm Biopharm. 2012;82(1):127-38.

43. Corrigan OI, Devlin Y, Butler J. Influence of dissolution medium buffer composition on ketoprofen release from ER products and in vitro-in vivo correlation. Int J Pharm. 2003;254(2):147-54.

44. Ozturk SS, Palsson BO, Dressman JB. Dissolution of ionizable drugs in buffered and unbuffered solutions. Pharm Res. 1988;5(5):272-82. 